\title{
Targeting CoV-2 Spike RBD and ACE-2 Interaction with Flavonoids of Anatolian Propolis by in silico and in vitro Studies in terms of possible COVID-19 therapeutics
}

\author{
Halil Ibrahim GULER ${ }^{1 *}$, Fulya AY SAL ${ }^{2}$, Zehra CAN ${ }^{3}$,Yakup KARA ${ }^{4}$, Oktay YILDIZ ${ }^{5}$, Ali \\ Osman BELDUZ ${ }^{2}$, Sabriye ÇANAKCI ${ }^{2}$, SevgiKOLAYLI ${ }^{4}$ \\ ${ }^{I}$ Karadeniz Technical University, Faculty of Science, Department of Molecular Biology and Genetics, \\ 61080 Trabzon, TURKEY \\ ${ }^{2}$ Karadeniz Technical University, Faculty of Science, Department of Biology, 61080 Trabzon, \\ TURKEY \\ ${ }^{3}$ School of Applied Sciences, Bayburt University, Bayburt, TURKEY, \\ ${ }^{4}$ Karadeniz Technical University, Department of Chemistry, Trabzon, TURKEY \\ ${ }^{5}$ Karadeniz Technical University, Faculty of Pharmacy, Basic Pharmaceutical Sciences, Department \\ of Biochemistry, 61080 Trabzon, TURKEY
}

\section{Corresponding author:}

Halil Ibrahim GULER

hiboguler@gmail.com, +90462 3773553

ORCID: 0000-0002-7261-6790

\section{Conflict of interest}

No conflict of interest is declared.

Running Title: Propolis and Covid-19 treatment 


\begin{abstract}
Propolis is a multi-functional bee product with a rich in polyphenols. In this study, the inhibition effect of Anatolian propolis against SARS coronavirus-2 (SARS CoV-2) was investigated as in vitro and in silico. Raw and commercial of propolis samples were used in the study and it was found that both of were rich in caffeic acid, p-coumaric acid, ferulic acid, t-cinnamic acid, hesperetin, chrysin, pinocembrin and caffeic acid phenethyl ester (CAPE) by HPLC-UV analysis. The ethanolic propolis extracts (EPE) were used in the screening ELISA test against the spike S1 protein (SARS Cov-2): ACE-2 inhibition KIT for in vitro study. Binding energy constants of these polyphenols to the CoV-2 Spike S1 RBD and ACE2proteinwere calculated separately as molecular docking study using AutoDock 4.2 molecular docking software. In addition, pharmacokinetics and drug-likeness properties of these eight polyphenols were calculated according to the SwissADME tool. Binding energy constant of pinocembrin was the highest for both of the receptors, followed by chrysin, CAPE and hesperetin. In silico ADME behavior of the eight polyphenols were found potential ability to work effectively as novel drugs. The findings of both studies showed that propolis has a high inhibitory potential against Covid-19 virus. However, further studies are needed.
\end{abstract}

Key words: Propolis, Covid-19, SARS CoV-2, pinocembrin, docking, EDM

\title{
1. INTRODUCTION
}

The severe acute respiratory syndrome (SARS) coronavirus-2 (SARS CoV-2) is responsible for coronavirus (COVID-19) pandemic. Coronavirus family has seventh member that infect human beings after SARS coronavirus and Middle East respiratory syndrome (MERS) coronavirus (Bachevski et al., 2020; Zhu et al., 2020). Compared with other viruses, this virus has a high transmissibility and infectivity and is mostly spread by respiratory tracts. The virus is transmitted directly or indirectly, mostly through mucous membranes, nose, mouth and eyes. Until an effective vaccine or medicine is found, many physical and chemical solutions are used to protect against this virus. Mask, distance and hygiene are the most widely used physical protective agents. There are some natural food supplements and vitamins are used in strengthening the immune system. The most used of them are vitamins D, C and propolis (Bachevski et al. 2020; Scorza et al., 2020). 
Propolis is a resinous honeybee product obtained from beehives as raw. Honeybees collect propolis mostly from the leaves, barks and trunks of the trees, then transform it with some secretions and store it in the hive. Honeybees benefit from propolis in physical, chemical and biological aspects (Bankova et al., 2019). They used it as antiseptic and antimicrobial, antiviral, antioxidant, antitumoral e.g. agents. Propolis has been also used extensively in traditional and complementary medicine for these wide biological activities (Pasupuleti et al., 2017). In the last 30 years, pharmacological and biochemical studies showed that propolis has wide biological active properties such as antibacterial, antiviral, anti-inflammatory, antitumoral, hepatoprotective, neuroprotective, enhanced immunity in apitherapeutic applications (Pasupuleti et al., 2017; Bankova et al., 2019; Kolayli et al., 2020).

Although its composition and biological active properties depend on the flora of the area where it is collected, propolis consists of approximately 50\% resin and balsam, 30\% wax, and the rest of essential oils and aromatic compounds (Bankova et al. 2019; Aliyazıcıoglu et al., 2011; Kiziltas and Erkan, 2020). The active ingredients of propolis, which consists of approximately 300 different organic compounds, are various polyphenols and volatile compounds found in the balsamic part. Although propolis is partially extracted by dissolving in water, glycol, vegetable oils, the most ideal solvent is 60-70\% ethanol (Oroian et al., 2020). Today many different commercial propolis extracts are available in different forms such as drops, sprays, pills, pastil, etc. The higher polyphenols or flavonoids contained propolis samples are accepted the higher qualities (Oroion et al., 2020). Polyphenols are the biggest of phytochemical compounds, and polyphenol-rich diets have been associated with many health benefits. Studies are strongly supports that dietary polyphenols is used in the prevention of degenerative diseases, particularly cardiovascular, neurodegenerative and cancers diseases (Tsao, 2010; Pasupuleti et al., 2017).

Propolis is a good antimicrobial and antiviral natural mixture (Przybyłek and Karpiński, 2019). Many studies have been shown that propolis has an antiviral effect againts various DNA and RNA viruses, such as HIV, Herpes simplex, HSV-1, HSV-2, para-influenza virus, influenza virus type A B, adenovirus, avian reovirus, Newcastle virus disease, bovine rotavirus, pseudo rabies virus etc. (Bachevski et al., 2020; Bankova et al., 2014). The oldest antiviral activity study of propolis against coronaviruses was conducted in 1990. In an in vitro study, only antiviral effects of five propolis flavonoids, chrysin, kaempferol, quercetin, acacetin and galangin were investigated. Among them, quercetin exhibited antiviral activity depending on the dose (Debiaggi et al., 1990). 
In the COVID-19 pandemic, propolis and some bee products have renewed interest against SARS CoV-2 infection, and some molecular docking studies have confirmed this. In silico studies are reported that some of the active ingredients of propolis, especially some flavonoids, have a higher binding potential than the antiviral drugs (Hydroxychloroquine and Remdesivir) used in COVID-19 spike protein and ACE-2 (Mady et al., 2020; Shaldam et al., 2020; Güler and Kara, 2020; Guler et al., 2020). In these studies, it has been shown that the active components of propolis have high binding potential to cellular Angiotensinconverting enzyme-2 (ACE-2) receptors of the S1 spike protein, serine protease TMPRSS2 and PAK1 signaling pathways (Beratta et al., 2020; Scorza et al., 2020). A clinical study was conducted in which propolis tablets were administered in PCR-positive Covid-19 patients (400 and $800 \mathrm{mg}$ ) (3x1) for 7 days together with placebo, the results showed that the propolis reduced hospitalization time (Silveira et al., 2021). Propolis also has immunomodulatory, anti-thrombosis activities (Beratta et al., 2020). These activities are also very important in combating the virus. In addition, propolis has been to inhibit the systemic inflammatory response and protect hepatic and neuronal cells in acute septic shock (Korish and Arafa, 2011).

Although propolis is one of the most commonly used natural prophylactic agents during the pandemic, the scientific studies on propolis are insufficient. Therefore, in this study, the inhibition of Anatolian propolis against COVID-19 virus was investigated for the first time in terms of the spike S1 protein (SARS CoV-2): ACE-2 inhibitor screening ELISA test as an in vitro study.

\section{MATERIALS AND METHODS}

\subsection{Chemicals}

ELISA KIT of COVID-19 spike protein:ACE-2 assay kit (Cat. No. 79954) was purchased from BPS Bioscience (79954), San Diego, USA gallic acid, protocatechuic acid p-OH benzoic acid, catechin, caffeic acid, syringic acid, epicatechin, p-coumaric acid, ferulic acid, rutin, myricetin, resveratrol, daidzein, luteolin, t-cinnamic acid, hesperedin, chrysin, pinocembrin, caffeic acid phenethyl ester (CAPE), $\mathrm{FeSO}_{4} \cdot 7 \mathrm{H}_{2} \mathrm{O}$, Folin-Ciocalteu's phenol, diethyl ether, ethyl acetate, acetonitrile were purchased from Sigma-Aldrich (Chemie, Munich, Germany). Daidzein from Cayman Chemical (Michigan, USA) and Ferric tripyridyl triazine (Fe-IIITPTZ), $\mathrm{FeCI}_{3}, \mathrm{CH}_{3} \mathrm{CO}_{2} \mathrm{Na} \cdot 3 \mathrm{H}_{2} \mathrm{O}$, acetonitrile purchased from Merck (Darmstadt, Germany). 


\subsection{Propolis samples}

Two different propolis samples were used in this study. Both propolis are samples of Anatolian flora, one was prepared from raw Anatolia propolis, the second was commercial Anatolia propolis. In order to obtain homogeneous Anatolian propolis sample (P1), propolis samples of seven different regions (Van, Rize, Zonguldak, Mugla, Antalya, Diyarbakır and Giresun) were mixed equally. $3 \mathrm{~g}$ of the powdered raw propolis was added $30 \mathrm{~mL} 70 \%$ ethanol and shaken on a shaker at a controlled speed for 24 hours (Heidolp Promax 2020, Schwabach, Germany), and ultrasonic (Everest Ultrasonic, Istanbul, Turkey) extraction has been applied for $30 \mathrm{~min}$ at $99 \%$ power adjustment, then the mixture was filtered through $0.2 \mu \mathrm{m}$ cellulose filters (Millipore, Bedford, MA, USA). The ethanolic propolis extract of the second samples elected among commercial propolis samples (P2), was supplied by Bee\&You (Bee'O®) (SBS Scientific Bio Solutions Inc., Istanbul, Turkey). The commercial propolis extract is sold in pharmacies and is widely used for apitherapeutic purposes in Turkey.

\subsection{Characterization of the propolis samples}

\subsubsection{Total phenolic compounds (TPC)}

Total phenolic content of the both samples were measured with Folin-Ciocalteu's test using gallic acid (GA) as standard (Singleton et al., 1999). $20 \mu \mathrm{L}$ six different propolis extracts and standard samples dilutions (from $0.500 \mathrm{mg} / \mathrm{mL}$ to $0.015 \mathrm{mg} / \mathrm{ml}$ ) and $0.2 \mathrm{~N} 400 \mu \mathrm{L}$ Folin reagents were mixed and completed to $5.0 \mathrm{ml}$ with distilled water, then vortexed. After 3 min incubation, $400 \mathrm{~mL}$ of $\mathrm{Na}_{2} \mathrm{CO}_{3}(10 \%)$ was added and incubated at $25^{\circ} \mathrm{C}$. The absorbance was measured at $760 \mathrm{~nm}$ after $2 \mathrm{~h}$ incubation. The total phenolic content was expressed in $\mathrm{mg}$ $\mathrm{GAE} / \mathrm{mL}$ using a standard curve.

\subsubsection{Total Flavonoid Content (TFC)}

Total flavonoid concentrations of the propolis samples were measured by spectrophotometric method using quercetin standard (Fukumoto and Mazza, 2000). $250 \mu \mathrm{L}$ of different propolis extracts and standard dilutions (from $0.500 \mathrm{mg} / \mathrm{mL}$ to $0,015 \mathrm{mg} / \mathrm{ml}$ ), $50 \mu \mathrm{L} \mathrm{mL}$ of $10 \%$ $\mathrm{Al}\left(\mathrm{NO}_{3}\right)_{3}$ and $50 \mu \mathrm{L}$ of $1 \mathrm{M} \mathrm{NH}_{4} \cdot \mathrm{CH}_{3} \mathrm{COO}$ was added and completed $3.0 \mathrm{~mL}$ with methanol (99\%), vortexed and incubated at $25^{\circ} \mathrm{C}$ for $40 \mathrm{~min}$. After incubation, the absorbance was then measured against a blank at $415 \mathrm{~nm}$. The total flavonoid concentration was expressed in $\mathrm{mg}$ QUE/ml by the curve. 


\subsubsection{Determination ferric reducing/antioxidant power (FRAP)}

The total antioxidant capacities of the samples were determined by using Ferric reducing/antioxidant power assay (FRAP)(Benzie \& Strain, 1999). Firstly, working FRAP reagent (Ferric tripyridyl triazine (Fe-III-TPTZ) was prepared. For this, it was freshly obtained by mixing $300 \mathrm{mM} \mathrm{pH}: 3.6$ acetate buffer, $10 \mathrm{mM}$ TPTZ and $20 \mathrm{mM} \mathrm{FeCl}_{3}$ solutions in a ratio of (10: 1: 1). Before the samples test, a standard curve is prepared with $1000 \mu \mathrm{M}$ stock $\mathrm{FeSO}_{4} .7 \mathrm{H}_{2} \mathrm{O}$ solution by serial dilutions. $1.500 \mathrm{ml}$ the FRAP reagent, $50 \mu \mathrm{L}$ sample and $50 \mu \mathrm{L}$ methanol were mixed and incubated for $4 \mathrm{~min}$ at $37^{\circ} \mathrm{C}$, and the absorbance was read at $595 \mathrm{~nm}$ against a reagent blank containing distilled water. FRAP value was expressed in $\mu \mathrm{mol}$ $\mathrm{FeSO}_{4} \cdot 7 \mathrm{H}_{2} \mathrm{O}$ equivalents/mL.

\subsubsection{Determination of phenolic compositions by HPLC-UV}

For preparation of the propolis extracts for chromatographic analysis, $10 \mathrm{ml}$ of ethanolic extracts were evaporated and the residue dissolved using $10 \mathrm{ml}$ of purified water of $\mathrm{pH}$ 2.The aqueous solution was extracted three times with $5 \mathrm{ml}$ of diethyl ether $(15 \mathrm{~min}, 200 \mathrm{rpm}, 25$ ${ }^{\circ} \mathrm{C}$ ) and three times with ethyl acetate $\left(15 \mathrm{~min}, 200 \mathrm{rpm}, 25^{\circ} \mathrm{C}\right)$. The organic phase, which was collected in a flask after each extraction, was evaporated. The residue was dissolved in 2 $\mathrm{mL}$ of methanol and filtered $0.45 \mu \mathrm{m}$ filters and given to HPLC device for analysis. The phenolic content analysis of the samples was done in triplicate.

Phenolic content analysis of the samples was performed with $280 \mathrm{~nm}$ wavelength in RPHPLC system (Elite LaChrome; Hitachi, Tokyo, Japan) with C18 column (150 mm * $4.6 \mathrm{~mm}$, $5 \mu \mathrm{m}$; Fortis). In the analysis using $70 \%$ acetonitrile/water (A) and $2 \%$ acetic acid/water (B) as mobile phase, the injection volume was $20 \mu \mathrm{l}$, the flow rate was $1.00 \mathrm{ml} / \mathrm{min}$ and the column temperature was $30^{\circ} \mathrm{C}$. The analysis was done using a gradient program. The R2 values of the calibration curves of the nineteen standard phenolic compounds used in the analysis were between 0.998 and 1.000 .

\subsection{Inhibition Assay for Covid-19}

The Spike S1 (SARS CoV-2): ACE-2 inhibitor scanning colorimetric assay kit (Cat. No. 79954) was purchased from BPS Bioscience (79954), San Diego, USA. The colorimetric test is designed for screening and profiling inhibitors of this interaction. The aim of the test is to prevent the virus from being entering the cell by preventing the interaction between Spike protein S1 and ACE-2. Using the kit protocol, the absorbance was read at $450 \mathrm{~nm}$ using $\mathrm{UV} / \mathrm{Vis}$ spectrophotometer microplate reader. The propolis and standard phenolic samples 
were diluted with $70 \%$ ethanol and the Covid-19/ELISA test procedure was applied. All tests were done in triplicate.

\subsection{Molecular Docking Studies}

AutoDock 4.2 software for performing molecular docking studies was used to investigate the possible interactions of eight ligands and reference molecule with the target proteins. To evaluate the prediction of accuracy of binding affinity between ligands and two target proteins, the binding free energies $(\Delta \mathrm{G})$ are calculated for the crystal structures and the docking mod. The 3-D structure of all ligands (pinocembrin, chrysin, cape, hesperetin, ferulic acid, t-cinnamic acid, p-coumaric acid, caffeic acid) and reference molecule (Hydroxychloroquine) were retrieved from the PubChem database (https://pubchem.ncbi.nlm.nih.gov/) as sdf format and then converted to pdb format by using BIOVIA DS Visualizer software (Dassault Systèmes BIOVIA, 2016).

\subsection{Pharmacokinetics and drug-likeness properties (ADME Prediction)}

In order for a drug to be effective, it must reach its target in the body in sufficient concentration and remain in bioactive form long enough for the expected biological events to occur there. Drug development involves absorption, distribution, metabolism and excretion (ADME) increasingly earlier stage in the discovery process, at a stage where the compounds are abundant but access to physical samples is limited (Daina et al., 2017). Pharmacokinetics, drug-likeness and medicinal chemistry properties of eight ligands were predicted using the Swiss ADME server. Important parameters related to ADME properties, such as Lipinski's five rules, drug solubility, pharmacokinetic properties, molar refraction and drug likeliness were analyzed. The SMILES format retrieved from PubChem Database of the interested ligands were used as input for analysis tool (Daina et al., 2017).

\subsection{Statistical analyses}

The statistical evaluations were carried out with the SPSS Statistic 11.5 (IBM SPSS Statistics, Armonk, New York, USA). For presenting the results, descriptive statistics were used as mean \pm SD. The correlation analyses were performed with Mann-Whitney U-test. The significance was determined at $\mathrm{p}<0.05$. 


\section{RESULTS}

\subsection{Propolis analyses}

Table 1 shows analysis of the two Anatolian propolis samples. The ethanolic propolis extracts, one was prepared from raw Anatolia propolis (P1) and the other was commercially available (P2). The $\mathrm{pH}$ values of both propolis samples were between 4.50 and 4.80, both of the found acidic. The total phenolic substance was found to be $12.30 \mathrm{mg}$ GAE/mL in P1 sample and $40.68 \mathrm{mg} \mathrm{GAE} / \mathrm{ml}$ in $\mathrm{P} 2$ sample. It was found that commercial sample (P2) has 3 times higher phenolic compound (P1). Similar to the total amount of phenolic content, the amount of total flavonoid substance was found to be different in both samples, and it was found to be $12.40 \mathrm{mg} / \mathrm{mL}$ in the commercial sample and $1.04 \mathrm{mg} / \mathrm{mL}$ in the P1 sample. Total antioxidant capacities of the samples were investigated only FRAP assay, and the results is showed that the commercial sample (P2) was higher two times than the other (P1). The phenolic profile results of two ethanolic propolis samples are summarized in Table 2. In the phenolic composition analyzes performed by HPLC-UV, it was found that both propolis samples contained similar phenolic components, but the flavonoids in the commercial sample (P2) were higher.

\subsection{Molecular Docking Studies}

The structures of the polyphenols used in the molecular docking program are given in Figure 1. The binding free energies values for ACE-2 and SARS-CoV-2 Spike RBD were calculated using the AutoDock 4.2 software program are summarized in Table 3. The docked poses, interacting residues and interactions of each ligand with ACE-2 and SARS CoV-2 Spike RBD are given in Figures 2-9. Details about estimated binding affinities $(\mathrm{kcal} / \mathrm{mol})$ and $\mathrm{K}_{\mathrm{i}}$ values of docked ligands are shown in the Table 3. The result of the study showed that four (pinocembrin, chrysin, caffeic acid phenethyl ester and hesperetin) were showed very low binding free energies to the ACE-2 receptor and SARS-CoV-2 Spike Protein RBD. It was also found that these four flavonoids have higher binding potential than hydroxychloroquine, which was used as a covid-19 drug and was used as the standard ligand in the study. From the Table 3, it can be clearly predicted that pinocembrin has the highest binding energy value of $8.58 \mathrm{kcal} / \mathrm{mol}$ for ACE-2 protein and $-7.54 \mathrm{kcal} / \mathrm{mol}$ for SARS CoV-2 Spike RBD, followed by chrysin owing dock scores of -8.47 and $-7.48 \mathrm{kcal} / \mathrm{mol}$, respectively. 


\subsection{Pharmacokinetics and drug-likeness properties (ADME Prediction)}

Table 4 shows the ADME properties of the polyphenols detected in the propolis samples. According to Lipinski, a compound to be used should have 5 properties to be selected as a potential drug. These are: (a) Molecular mass <500 Daltons (b) high lipophilicity (expressed as $\log$ P 5) (c) less than 5 hydrogen bond donors (d) less than 10 hydrogen bond acceptors (e) molar refractivity between 40 and 130. The scanned eight flavonoid compounds used in this study were all found to meet the Lipinski's five rules (Table 4). And also, other properties like pharmaco-kinetic, physicochemical and drug-likeness properties are given in Table 4. The results were indicated that all of eight molecules have the potential to work effectively as novel drugs.

\subsection{In vitro inhibition studies}

The binding of ACE-2 protein to SARS CoV-2 Spike S1 protein was studied for both EPEs with the inhibitor screening colorimetric assay kit (BPS Bioscience, 79954). The key to this ELISA assay is the high sensitivity of detection of ACE-2-Biotin protein by StreptavidinHRP. This technique is based on the binding of the active ingredients of the propolis to this spike S1 protein/ACE-2 complex and preventing the binding of the enzyme-labeled second antibody to the protein. The presence of enzyme activity (horseradish peroxidase) indicates the absence of binding. The inhibition values are expressed in terms of the $\mathrm{IC}_{50}$ value, and are expressed as the amount of the propolis that provides 50\% inhibition. The data are shown in Figures 10-11. Together with the propolis samples, ability of certain flavonoids to inhibit the interaction of SARS CoV-2 S1 spike protein and ACE-2 were also tested. It was found that the two EPE samples were found to cause inhibition of interaction of SARS CoV-2 S1 spike protein: ACE-2 receptors and the degree of inhibition $\left(\mathrm{IC}_{50}\right)$ varied depending on the propolis concentration. The $\mathrm{IC}_{50}$ value of the commercial propolis was found to be about 3 times higher than P1 sample.

In the study, inhibition effect of five different concentrations of hesperetin, CAPE and pinocembrin were tested with the ELISA plate assay was. It was determined that the inhibition values were varied depending on the concentration (Fig 10). Hesperetin is the best inhibitor againts the SARS CoV-2 S1 spike protein and ACE-2, has the lowest $\mathrm{IC}_{50}$ value (16.88 $\mathrm{mM})$, pinocembrin and CAPE were followed them. When comparing in silico and in vitro study results, it is found that pinocembrin had a high inhibitory effect in in silico study, whereas hesperetin was more active in in vitro study. 


\section{DISCUSSION}

Propolis is a natural bee product and a very good source of polyphenols. The ideal extraction solvent for propolis rich in phenolic acid and flavonoids is $70 \%$ ethanol. The most characteristic analysis parameters for propolis are total polyphenol, total flavonoid and phenolic content analysis. It was determined that the phenolic amount of the two ethanolic propolis samples were found similar in terms of their composition, but different in terms of amounts. The main reason for this difference is the amount of the raw propolis that used initially when extracting with solvent (70\%). In the P1 sample, $3 \mathrm{~g}$ of raw propolis was prepared at a ratio of $1: 10$ in $30 \mathrm{~mL} 70 \%$ alcohol. However, since the P2 sample is commercial, it is not known how much raw propolis is used; it is only possible to say that it is used in higher amounts than P1 sample. In short, the extract prepared with a high amount of raw propolis is expected to have a higher amount of phenolic matter. However, the quality of raw propolis used in extraction is also important parameter (Yeo et al., 2015). It has been reported that total polyphenol content (TPC) in Anatolian raw propolis samples varied from $115 \mathrm{mg} \mathrm{GAE} / \mathrm{g}$ to $210 \mathrm{mg} \mathrm{GAE} / \mathrm{g}$ (Aliyazıcıoglu et al., 2011). It was reported that TPC is varied from 55.75 to $91.32 \mathrm{mg} \mathrm{GAE} / \mathrm{g}$ in Brazilian propolis (Andrade et al., 2017) and TPC was varied from 10 to $80 \mathrm{mg} \mathrm{GAE} / \mathrm{g}$ in Azerbaijan propolis (Zehra et al., 2015). These results show that the amount of total polyphenol in propolis quality is a critical criterion and at the same time, this quality depends on the flora.

The samples were also found acidic, $(\mathrm{pH}<6.0)$ that the acidity are sourced from organic acid that were found in the propolis. Caffeic acid, p-coumaric acid, and ferulic acids were detected both of the samples. However, it was reported that gallic acid, caffeic acid, coumaric acid, ferulic acid and syringic acid, protocathequic acid are major phenolic acids in propolis samples (Yeo et al., 2015; Aliyazıcıoglu et al. 2011). Gallic acid, protocathequic acid, p-OH benzoic acid, syringic acid were not detected in any sample, but this does not mean that there will be no gallic acid in Anatolian propolis (Keskin et al., 2019). Because these phenolic acids are highly polar compounds, they may not have switched to ethanol with a lower polarity than water. CAPE, pinocembrin and chrysin were found the most abundant flavonoids in both of the samples. CAPE is a polyphenol found mostly in propolis, and its high amount reflects the quality of propolis and possessed a wide biological active properties such as antioxidant, anti-inflammatory, anti-tumoral etc. (Aliyazıcıoglu et al., 2011; Bankova et al., 2014; Bankova et al., 2019; Venkateswara et al., 2017).

Pinocembrin, hesperetin and chrysin were also found abundant flavonoids in the EPEs. Flavonoids are the most common and the largest plant polyphenolic obtained from the 
everyday plant-source diet (Chun et al., 2007), and have been proven to be responsible for a variety of biological activities such as antioxidant, antibacterial, antiviral and antiinflammatory activity. Amount of flavonoids taken in the daily diet was estimated to be about $200 \mathrm{mg} / \mathrm{day}$, and it consisted of $84 \%$ flavan-3-ols, flavanones (7.6\%), flavonols (7\%), anthocyanidins $(1.6 \%)$, flavones $(0.8 \%)$ and isoflavones $(0.6 \%)$. However, epidemiological studies conducted in populations fed with flavonoid-rich diets have shown that the incidence of cardiovascular damage and some types of it has decreased (Cui et al., 2008). It has been supported by studies that propolis is a very good source of flavonoids (Venkateswara et al., 2017; Kowacz and Pollack, 2020). Thus, high polyphenols and flavonoids are taken together with consumption of propolis as a food supplement.

The antioxidant capacity of the EPEs was measured according to the FRAP test, and this test is a very simple and easy test that shows the total antioxidant capacity. The higher the FRAP value in the analysis measured according to the reduction ability of the Fe (III) TPTZ complex, the higher the antioxidant capacity (Can et al., 2015). It was determined that the antioxidant capacity of the commercial propolis sample (P2) was approximately 2 times higher than the other sample (P1). The high antioxidant capacity in the commercial propolis sample is thought to be due to the high polyphenol content (Can et al. 2015; Kolayli et al., 2020).

Molecular docking is a crucial tool for exploring the interactions between the target protein and a small molecule. The binding energy $(\mathrm{kcal} / \mathrm{mol})$ data allows us to study and compare the binding affinity of different ligands/compounds with their corresponding target receptor molecule. The lower binding energy indicates a higher affinity of the ligand for the receptor. The ligand with the highest affinity can be selected as a potential drug for further studies. For this study, eight flavonoids with a broad range of biological activities, along with hydroxychloroquine which exhibited efficacy against SARS CoV-2, have been selected as ligands to investigate their binding affinities with SARS CoV-2 Spike Protein RBD and ACE2 as target receptor proteins. All the eight polyphenols and one reference molecule were individually docked to the ACE-2 and SARS CoV-2 Spike RBD, respectively. After successful docking of all the ligands used in these docking experiments, the results showed us significant interactions of the ligands with the target receptors. Four ligands (pinocembrin, chrysin, CAPE and hesperetin) are bound to the target protein ACE-2 more effectively than the reference molecule. And also, seven ligands (pinocembrin, chrysin, hesperetin, CAPE, ferulic acid, t-cinnamic acid and caffeic acid) are bound stronger to the SARS CoV-2 spike RBD than the reference molecule, hydroxychloroquine. The docking study results that 
pinocembrin has the highest binding energy value of $-8.58 \mathrm{kcal} / \mathrm{mol}$ for ACE-2 protein and $7.54 \mathrm{kcal} / \mathrm{mol}$ for SARS CoV-2 Spike RBD, followed by chrysin owing dock scores of -8.47 and $-7.48 \mathrm{kcal} / \mathrm{mol}$, respectively. In molecular docking studies with propolis and Covid-19, it has been reported that some propolis flavonoids have high binding affinities to ACE-2 receptors and the virus spike protein. For example, Quercetin and rutin have been reported to have similar activity (Basu et al., 2020; Guler et al., 2020; Guler and Kara, 2020; Mady et al., 2020; Berretta et al., 2020).

The rule essentially determines the molecular properties of a compound that are its primary requirement for being a potential drug, such as absorption, distribution, metabolism, and excretion (ADME). Generally, some parameters are used to evaluate potential interactions between drug and other non-drug target molecules (Das, et al., 2020; Gupta et al.,2020; Jayaram et al., 2012; Lipinski, 2004). The propensity for a compound with a certain pharmacological or biological activity to be used as a potential drug is evaluated. It was found that these eight polyphenols detected in these propolis samples were meet the five rules of Lipinski and other features were also compactable. Hence, we suggest that the flavonoids have the potential to work effectively as novel drugs.

The aim of the study was to investigate the inhibition potential of ethanolic propolis extracts by binding to SARS CoV-2 Spike protein and ACE-2, so two propolis extracts were used in the study. In in vitro study, it was found that both samples caused inhibition, but the P2 sample showed higher activity. This is thought to be due to the higher polyphenol content of the P2 sample. The result that the 3 different polyphenols (hesperetin, pinocembrin and CAPE) studied separately cause inhibition of the virus shows us that the active substances in propolis are mostly due to flavonoids. Since no in vitro study was reported before, we could not compare and discuss our results. All eight phenolic standards were not tested as in vitro by the ELISA KIT assay, since the plate was limited to 96 well plates. As a result of in silico study, the in vitro inhibitions of three flavonoids with the highest binding potential were examined.

When comparing in silico study results with in vitro study results, it is seen that pinocembrin, hesperetin and CAPE have high binding affinities to virus spike S1 protein and ACE-2 receptor. So, in silico and in vitro studies support each other. In addition, the fact is that the phenolic standards used in terms of ADME properties were found to have high drug properties and the results proved that propolis has high potential in combating the Covid- 19 . 


\section{CONCLUSION}

In this study, it was shown for the first time that ethanolic Anatolia propolis extracts inhibit Covid-19 virus in terms of binding spike S1 protein and ACE-2 receptor as both in vitro and in silico studies. However, more detailed studies are needed.

\section{Acknowledgments}

This work was supported by the KTU BAP FBA-2020-9192 project. We thank (Bee\&You (Bee'O®) (SBS Scientific Bio Solutions Inc., Istanbul, Turkey) company for allowing the use of commercial propolis sample.

\section{REFERENCES}

Aliyazıcıoglu, R., Sahin, H., Erturk, O., Ulusoy, E., \& Kolayli, S. (2013). Properties of phenolic composition and biological activity of propolis from Turkey. International Journal of Food Properties, 16, 277-287. doi.org/10.1080/10942912.2010.551312.

Andrade, J. K. S., Denadai, M., de Oliveira, C. S., Nunes, M. L., \& Narain, N. (2017). Evaluation of bioactive compounds potential and antioxidant activity of brown, green and red propolis from Brazilian northeast region. Food Research International, 101, 129-138. doi.org/10.1016/j.foodres.2017.08.066.

Bachevski, D., Damevska, K., Simeonovski, V., \& Dimova, M. (2020). Back to the basics: Propolis and COVID-19. Dermatologic Therapy, 33(4), e13780. doi.org/10.1111/dth.13780

Bankova, V., Bertelli, D., Borba, R., Conti, B. J., da Silva Cunha, I. B., Danert, C., ..\& Zampini, C. (2019). Standard methods for Apis mellifera propolis research. Journal of Apicultural Research, 58(2), 1-49. doi.org/10.1080/00218839.2016.1222661.

Bankova, V., Galabov, A. S., Antonova, D., Vilhelmova, N., \& Di Perri, B. (2014). Chemical composition of propolis extract $\mathrm{ACF} 囚$ and activity against herpes simplex virus. Phytomedicine, 21(11), 1432-1438. doi.org/10.1016/j.phymed.2014.04.026

Basu, A., Sarkar, A., \& Maulik, U. (2020). Molecular docking study of potential phytochemicals and their effects on the complex of SARS-CoV2 spike protein and human ACE2. Scientific reports, 10(1), 1-15.

Benzie, I.F.F.; Strain, J.J. (1999). Ferric Reducing/Antioxidant Power Assay: Direct measure of total antioxidant activity of biological fluids and modified version for simultaneous measurement of total antioxidant power and ascorbic acid concentration. Methods in Enzymology, 299, 15-27. doi.org/10.1016/S0076-6879(99)99005-5. 
Berretta, A.A, Silveira, M.A.D, Capcha, J.M.C \& De Jong, D. (2020). Propolis and its potential against SARS-CoV-2 infection mechanisms and COVID-19 disease, Biomedicine \& Pharmacotherapy, 110622. doi.org/10.1016/j.biopha.2020.110622

Çakir, H. E., Şirin, Y., Kolayli, S., \& Can Z. (2018). Validation methods for phenolic components with RP-HPLC-UV in various bee products. Apiterapive Doğa Dergisi, 1(1), 13-19.

Can, Z., Yildiz, O., Sahin, H., Turumtay, E. A., Silici, S., \& Kolayli, S. (2015). An investigation of Turkish honeys: their physico-chemical properties, antioxidant capacities and phenolic profiles. Food Chemistry, 180, 133-141. doi.org/10.1016/j.foodchem.2015.02.024.

Chun, O. K., Chung, S. J., \& Song, W. O. (2007). Estimated dietary flavonoid intake and major food sources of US adults. The Journal of nutrition, 137(5), 1244-1252. doi.org/10.1093/jn/137.5.1244.

Cui, Y., Morgenstern, H., Greenland, S., Tashkin, D. P., Mao, J. T., Cai, L., \& Zhang, Z. F. (2008). Dietary flavonoid intake and lung cancer-A population-based case-control study. Cancer, 112(10), 2241-2248. doi.org/10.1002/cncr.23398.

Daina, A., Michielin, O., \& Zoete, V. (2017). Swiss ADME: a free web tool to evaluate pharmacokinetics, drug-likeness and medicinal chemistry friendliness of small molecules. Scientific Reports, 7, 42717. doi.org/10.1038/srep42717.

Das, S., Sarmah, S., Lyndem, S., \& Singha Roy, A. (2020). An investigation into the identification of potential inhibitors of SARS-CoV-2 main protease using molecular docking study. Journal of Biomolecular Structure and Dynamics, 1-11. doi.org/10.1080/07391102.2020.1763201.

Dassault Systèmes BIOVIA, Discovery Studio Modeling Environment, Release 2017, San Diego: Dassault Systèmes, 2016.

Debiaggi, M, Tateo, F, Pagani, L, Luini, M. \& Romero, E. (1990). Effects of propolis flavonoids on virus infectivity and replication. Microbiologica, 13, (3) 207-213.

Fukumoto L.R., Mazza G. (2000). Assessing antioxidant and prooxidant activities of phenolic compounds. Journal Agriculture Food Chemistry, 48, 3597-3604. doi.org/10.1021/jf000220w.

Güler, H. İ. and Kara Y. Targeting CoV-2 Spike RBD: ACE-II complex with phenolic compounds from Cistus (Cistus L.) Bee Pollen for COVID-19 treatment by Molecular Docking Study. Apiterapi ve Doğa Dergisi, 3(1), 10-23. 
Güler, H. I., Tatar, G., Yildiz, O., Belduz, A. O., \& Kolayli, S. (2020). Investigation of potential inhibitor properties of ethanolic propolis extracts against ACE-II receptors for COVID-19 treatment by Molecular Docking Study. Science Open Preprints.

Gupta, M. K., Vemula, S., Donde, R., Gouda, G., Behera, L., \& Vadde, R. (2020). In-silico approaches to detect inhibitors of the human severe acute respiratory syndrome corona virus envelope protein ion channel. Journal of Biomolecular Structure. doi.org/10.1080/07391102.2020.1751300.

Jayaram, B., Singh, T., Mukherjee, G., Mathur, A., Shekhar, S., \& Shekhar, V. (2012). Sanjeevini: A freely accessible web-server for target directed lead molecule discovery. BMC Bioinformatics, 13 (Suppl 17), S7. doi.org/10.1186/1471-2105-13-S17-S7

Keskin, M., Keskin, Ş., \& Kolayli, S. (2019). Preparation of alcohol free propolis-alginate microcapsules, characterization and release property. LWT-Food Science and Technology, 108, 89-96. doi.org/10.1016/j.lwt.2019.03.036

Kiziltas, H., \&Erkan, C. (2020).The effects of different beehives on propolis production and quality. Food Science and Technology, (AHEAD).

Kolayli, S., Palabiyik, I., Atik, D. S., Keskin, M., Bozdeveci, A., \& Karaoglu, S. A. (2020). Comparison of antibacterial and antifungal effects of different varieties of honey and propolis samples. Acta Alimentaria, 49(4), 515-523. doi. 10.1556/066.2020.49.4.18

Korish, A. A., \& Arafa, M. M. (2011). Propolis derivatives inhibit the systemic inflammatory response and protect the hepatic and neuronal cells in acute septic shock. The Brazilian Journal of Infectious Diseases, 15(4), 332-338. doi.org/10.1016/S1413-8670(11) 70201-X.

Kowacz, M., \&Pollack, G. H. (2020). Propolis-induced exclusion of colloids: Possible new mechanism of biological action. Colloid And Interface Science Communications, 38, 100307. doi.org/10.1016/j.colcom.2020.100307.

Lipinski, C. A. (2004). Lead- and drug-like compounds: The rule-of-five revolution. Drug Discov Today Technol, 1(4), 337-341. doi.org/ 10.1016/j.ddtec.2004.11.007.

Mady, F. M., Sarhan, H. A., Rateb, H. S., \& Alaaeldin, E. (2020). Optimization and Evaluation of propolis liposomes as a promising therapeutic approach for COVID-19. $\begin{array}{llll}\text { International Journal of } & & \end{array} 20028$. doi.org/10.1016/j.ijpharm.2020.120028.

Malkoç, M., Çakir, H., Yakup, K. A. R. A., Zehra, C. A. N., \& Kolayli, S. (2019). Phenolic composition and antioxidant properties of Anzer honey from Black Sea Region of Turkey. Uludağ Arıcılık Dergisi, 19(2), 143-151. doi.org/10.31467/uluaricilik.602906 
Morris, G. M., Huey, R., Lindstrom, W., Sanner, M. F., Belew, R. K., Goodsell, D. S., \& Olson, A. J. (2009). AutoDock4 and AutoDockTools4: Automated docking with selective receptor flexibility. Journal of Computational Chemistry, 30(16), 2785-2791. doi.org/10.1002/jcc.21256.

Oroian, M., Ursachi, F., \& Dranca, F. (2020). Influence of ultrasonic amplitude, temperature, time and solvent concentration on bioactive compounds extraction from propolis. Ultrasonics Sonochemistry, 64, 105021. doi.org/10.1016/j.ultsonch.2020.105021

Pasupuleti, V. R., Sammugam, L., Ramesh, N., \& Gan, S. H. (2017). Honey, propolis, and royal jelly: a comprehensive review of their biological actions and health benefits. Oxidative Medicine and Cellular Longevity, 2017. doi.org/10.1155/2017/1259510.

Przybyłek, I., \& Karpiński, T. M. (2019). Antibacterial properties of propolis. Molecules, 24(11), 2047. doi.org/10.3390/molecules24112047.

Scorza, C. A., Gonçalves, V. C., Scorza, F. A., Fiorini, A. C., de Almeida, A. C. G., Fonseca, M. C., \& Finsterer, J. (2020). Propolis and coronavirus disease 2019 (COVID-19): Lessons from nature. Complementary Therapies in Clinical Practice, 41, 101227. doi: 10.1016/j.ctcp.2020.101227.

Shaldam, M. A., Yahya, G., Mohamed, N. H., Abdel-Daim, M. M., \& Al Naggar, Y. (2020). In silico screening of potent bioactive compounds from honey bee products against COVID-19 target enzymes. ChemRxiv, 12644102, 1-18. doi.org/10.26434/chemrxiv.12644102.v1.

Silveira, M. A. D., De Jong, D., dos Santos Galvão, E. B., Ribeiro, J. C., Silva, T. C., Berretta, A. A., ... \& da Hora Passos, R. (2021). Efficacy of propolis as an adjunct treatment for hospitalized COVID-19 patients: a randomized, controlled clinical trial. MedRxiv.

Singleton V.L., Orthofer R. and Lamuela-Raventos R.M. (1999). Analysis of total phenols and other oxidation substrates and antioxidants by means of folin-ciocalteu reagent, Methods in Enzymology, 299, 152-178. doi.org/10.1016/S0076-6879(99)99017-1.

Tsao, R. (2010). Chemistry and biochemistry of dietary polyphenols. Nutrients, 2(12), 12311246. doi.org/10.3390/nu2121231.

Venkateswara, R., P., Kiran, S. D. V. S., Rohini, P., \& Bhagyasree, P. (2017). Flavonoid: a review on naringenin. J. Pharmacogn. Phytochem, 6, 2778-2783.

Yeo, K. L., Leo, C. P., \& Chan, D. J. C. (2015). Ultrasonic enhancement on propolis extraction at varied $\mathrm{pH}$ and alcohol content. Journal of Food Process Engineering, 38(6), 562-570. doi.org/10.1111/jfpe.12186. 
Zehra, C., Yildiz, O., Şahin, H., Asadov, A., \&Kolayli, S. (2015). Phenolic profile and antioxidant potential of propolis from Azerbaijan. Mellifera, 15(1), 16-28.

Zhu, X., Ge, Y., Wu, T., Zhao, K., Chen, Y., Wu, B., ...\& Cui, L. (2020). Co-infection with respiratory pathogens among COVID-2019 cases. Virus Research, 285, 198005. doi.org/10.1016/j.virusres.2020.198005. 
bioRxiv preprint doi: https://doi.org/10.1101/2021.02.22.432207· this version posted February 23, 2021. The copyright holder for this preprint (which was not certified by peer review) is the author/funder, who has granted bioRxiv a license to display the preprint in perpetuity. It is made available under aCC-BY-NC-ND 4.0 International license.

Table 1. Analysis of two Anatolian propolis samples

\begin{tabular}{llllll}
\hline & $\mathbf{p H}$ & $\begin{array}{l}\text { Total Phenolic } \\
\text { Content } \\
(\mathbf{m g G A E} / \mathbf{m L})\end{array}$ & $\begin{array}{l}\text { Total Flavanoid } \\
\text { Content } \\
(\mathbf{m g Q U E} / \mathbf{m L})\end{array}$ & $\begin{array}{l}\text { Total Antioxidant } \\
\text { Capacity (FRAP) } \\
\boldsymbol{\mu m o l F e S O} / \mathbf{m L})\end{array}$ \\
\cline { 2 - 6 } P1 & $\begin{array}{l}\text { Raw Propolis } \\
\text { (Prepared by self) }\end{array}$ & $4.80 \pm 0.01$ & $12.30 \pm 0.02$ & $1.08 \pm 0.03$ & $141.40 \pm 1.70$ \\
P2 & $\begin{array}{l}\text { Commercial Propolis } \\
\text { (BEE'O)@ }\end{array}$ & $4.50 \pm 0.01$ & $40.68 \pm 1.50$ & $12.40 \pm 0.98$ & $285.40 \pm 5.40$ \\
\hline
\end{tabular}


Table 2. Phenolic profile of the EPE samples by HPLC-UV

\begin{tabular}{|c|c|c|}
\hline $\begin{array}{l}\text { Phenolic Standards } \\
(\mathrm{mg} / 100 \mathrm{~g})\end{array}$ & $\begin{array}{l}\text { Raw Propolis } \\
\text { (P1) } \\
\text { (Prepared by self) }\end{array}$ & $\begin{array}{l}\text { Commercial } \\
\text { Propolis } \\
\left(\mathrm{BEE}^{\prime} \mathrm{O}\right) @(\mathbf{P 2}) \\
\end{array}$ \\
\hline Gallic acid & - & - \\
\hline Protocathequic acid & - & - \\
\hline$p$-OH Benzoic acid & - & - \\
\hline Catechin & - & - \\
\hline Caffeic acid & 707.71 & 497.27 \\
\hline Syringic acid & - & - \\
\hline Epicatechin & - & - \\
\hline$p$-Coumaric acid & 881.89 & 269.02 \\
\hline Ferulic Acid & 378.53 & 145.77 \\
\hline Rutin & - & - \\
\hline Myricetin & - & - \\
\hline Resveratrol & - & \\
\hline Daidzein & - & - \\
\hline Luteolin & - & - \\
\hline$t$-Cinnamic acid & 510.47 & 51.75 \\
\hline Hesperetin & 711.06 & 3029.46 \\
\hline Chrysin & 665.11 & 1190.89 \\
\hline Pinocembrin & 1685.48 & 1804.22 \\
\hline CAPE & 3268.72 & 3168.26 \\
\hline
\end{tabular}

(-):not detected 
Table 3. Summary of estimated binding affinity ( $\mathrm{kcal} / \mathrm{mol}$ ) and $\mathrm{K}_{\mathrm{i}}$ values of docked ligands against ACE2 and SARS-CoV-2 Spike receptor binding domain, and interacted residues in the binding sites.

\begin{tabular}{|c|c|c|c|c|}
\hline $\begin{array}{l}\text { Receptor Name / PDB } \\
\text { ID }\end{array}$ & Ligand Name & $\begin{array}{l}\text { Binding } \\
\text { Energy } \\
\text { (kcal/mol) }\end{array}$ & $\mathbf{K}_{\mathbf{i}}$ & $\begin{array}{l}\text { Interacted residues with } \\
\text { ligand }\end{array}$ \\
\hline \multirow{9}{*}{$\begin{array}{l}\text { Angiotensin-Converting } \\
\text { Enzyme-2 } \\
\text { (ACE-2) } \\
\text { EC: } 3.4 .17 .23\end{array}$} & Pinocembrin & -8.58 & $510.99 \mathrm{nM}$ & $\begin{array}{l}\text { Asn210, Leu9, Pro565, Ser563, } \\
\text { Leu91, Val212, Val209 }\end{array}$ \\
\hline & Chrysin & -8.47 & $623.53 \mathrm{nM}$ & $\begin{array}{l}\text { Asn210, Val212, Ser563, } \\
\text { Glu564, Leu91, Leu95, Pro565, } \\
\text { Val209 }\end{array}$ \\
\hline & $\begin{array}{l}\text { CAPE } \\
\text { (Caffeic acid phenethyl } \\
\text { ester) }\end{array}$ & -8.42 & $677.67 \mathrm{nM}$ & $\begin{array}{l}\text { Asn437, Ile291, Thr434, } \\
\text { Phe438, Pro415 }\end{array}$ \\
\hline & Hesperetin & -8.22 & $943.94 \mathrm{nM}$ & $\begin{array}{l}\text { Leu91, Ser63, Asn210, Asp206, } \\
\text { Va1209, Trp566, Val212, } \\
\text { Glu564, Pro565, Leu95 }\end{array}$ \\
\hline & Ferulic acid & -5.65 & $72.03 \mu \mathrm{M}$ & $\begin{array}{l}\text { His540, Ile291, Pro289, Thr434, } \\
\text { Glu430 }\end{array}$ \\
\hline & t-Cinnamic acid & -5.65 & $72.06 \mu \mathrm{M}$ & $\begin{array}{l}\text { Leu456, Trp477, Leu503, } \\
\text { Trp165, Trp271, Lys481 }\end{array}$ \\
\hline & p-coumaric acid & -5.63 & $74.21 \mu \mathrm{M}$ & $\begin{array}{l}\text { Trp165, Pro500, Leu503, } \\
\text { Leu456, Trp477, Lys481, } \\
\text { Trp271 }\end{array}$ \\
\hline & Caffeic acid & -5.31 & $127.93 \mu \mathrm{M}$ & $\begin{array}{l}\text { Leu73, Ala99, Leu100, Lys74, } \\
\text { Asn103 }\end{array}$ \\
\hline & *Hydroxychloroquine & -7.90 & $1.61 \mu \mathrm{M}$ & $\begin{array}{l}\text { Arg393, Phe390, Leu391, } \\
\text { Asn394, His378, His401, } \\
\text { Asp350 }\end{array}$ \\
\hline \multirow{9}{*}{$\begin{array}{l}\text { SARS-CoV-2 Spike } \\
\text { receptor binding domain } \\
\text { / } \\
\text { 6YLA (Chain A) } \\
\text { Res: } 2.42 \AA\end{array}$} & Pinocembrin & -7.54 & $2.99 \mu \mathrm{M}$ & $\begin{array}{l}\text { Asn } 448, \text { Tyr449, Tyr451, } \\
\text { Tyr495, Lys444, Phe } 497\end{array}$ \\
\hline & Chrysin & -7.48 & $3.29 \mu \mathrm{M}$ & $\begin{array}{l}\text { Asn } 448, \text { Tyr449, Phe } 497, \\
\text { Tyr495 }\end{array}$ \\
\hline & Hesperetin & -7.28 & $4.63 \mu \mathrm{M}$ & $\begin{array}{l}\text { Ile472, Asp467, Phe456, } \\
\text { Arg457, Pro491, Lys458, } \\
\text { Gln474 }\end{array}$ \\
\hline & CAPE & -7.17 & $5.54 \mu \mathrm{M}$ & $\begin{array}{l}\text { Leu335, Phe338, Val367, } \\
\text { Trp436, Gly339, Cys336 }\end{array}$ \\
\hline & Ferulic acid & -6.93 & $8.29 \mu \mathrm{M}$ & Leu441, Tyr495 \\
\hline & t-Cinnamic acid & -6.64 & $13.57 \mu \mathrm{M}$ & $\begin{array}{l}\text { Phe497, Lys444, Asn448, } \\
\text { Tyr449, Tyr495 }\end{array}$ \\
\hline & Caffeic acid & -6.43 & $19.36 \mu \mathrm{M}$ & Leu441, Tyr495, Phe497 \\
\hline & p-coumaric acid & -5.97 & $42.06 \mu \mathrm{M}$ & Phe497, Tyr495, Leu441 \\
\hline & *Hydroxychloroquine & -6.32 & $23.35 \mu \mathrm{M}$ & $\begin{array}{l}\text { Leu517, Tyr396, Val382, } \\
\text { Phe392, Thr430, Phe515 }\end{array}$ \\
\hline
\end{tabular}

*reference molecule 
Table 4. ADME properties of ligands docked with SARS-CoV-2 Spike RBD and ACE-2 target proteins

\begin{tabular}{|c|c|c|c|c|c|c|c|c|c|c|c|c|c|c|c|c|c|c|}
\hline \multirow[b]{2}{*}{ Ligand name } & \multicolumn{5}{|c|}{ (Lipinski's Rule of Five) } & \multirow[b]{2}{*}{$\begin{array}{l}\text { Heavy } \\
\text { atoms }\end{array}$} & \multirow[b]{2}{*}{$\begin{array}{l}\text { Aromatic } \\
\text { heavy } \\
\text { atoms }\end{array}$} & \multirow[b]{2}{*}{$\begin{array}{l}\text { Rotat. } \\
\text { bonds }\end{array}$} & \multirow[b]{2}{*}{ TPSA } & \multirow[b]{2}{*}{$\begin{array}{l}\text { ESOL } \\
\text { Class }\end{array}$} & \multirow[b]{2}{*}{$\begin{array}{l}\text { GI } \\
\text { absorption }\end{array}$} & \multirow[b]{2}{*}{$\begin{array}{l}\text { BBB } \\
\text { permeant }\end{array}$} & \multirow[b]{2}{*}{$\begin{array}{l}\text { Pgp } \\
\text { substrate }\end{array}$} & \multirow[b]{2}{*}{$\begin{array}{l}\text { Bio } \\
\text { Avail. } \\
\text { Score }\end{array}$} & \multirow[b]{2}{*}{$\begin{array}{l}\text { PAINS } \\
\text { alerts }\end{array}$} & \multirow[b]{2}{*}{$\begin{array}{l}\text { Synthetic } \\
\text { Accessibility }\end{array}$} & \multirow[b]{2}{*}{ Violations } & \multirow[b]{2}{*}{$\begin{array}{l}\text { Drug } \\
\text { Likeliness }\end{array}$} \\
\hline & $\begin{array}{l}\text { Mol. } \\
\text { weight }\end{array}$ & $\log P$ & \begin{tabular}{|l|} 
H- \\
bond \\
donor
\end{tabular} & $\begin{array}{l}\text { H-bond } \\
\text { acceptor }\end{array}$ & $\begin{array}{l}\text { Molar } \\
\text { Refractivity }\end{array}$ & & & & & & & & & & & & & \\
\hline Pinocembrin & 256.25 & 2.26 & 2 & 4 & 69.55 & 19 & 12 & 1 & $66.76 \AA$ & soluble & High & Yes & No & 0.55 & 0 & 2.96 & No & Yes \\
\hline Chrysin & 254.24 & 2.5 & 2 & 4 & 71.97 & 19 & 16 & 1 & $70.67 \AA$ & $\begin{array}{c}\text { moderately } \\
\text { soluble }\end{array}$ & High & Yes & No & 0.55 & 0 & 2.93 & No & Yes \\
\hline CAPE & 284.31 & 3.26 & 2 & 4 & 80.77 & 21 & 12 & 6 & $66.76 \AA$ & $\begin{array}{l}\text { moderately } \\
\text { soluble }\end{array}$ & High & Yes & No & 0.55 & 1 & 2.64 & No & 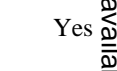 \\
\hline Hesperetin & 302.28 & 1.91 & 3 & 6 & 78.06 & 22 & 12 & 2 & $66.76 \AA$ & soluble & High & No & Yes & 0.55 & 0 & 3.22 & No & Yes $\stackrel{0}{\stackrel{0}{\Phi}}$ \\
\hline Ferulic acid & 194.18 & 1.36 & 2 & 4 & 51.63 & 14 & 6 & 3 & $66.76 \AA$ & soluble & High & Yes & No & 0.85 & 0 & 1.93 & No & Yes $\stackrel{\vec{D}}{\mathbb{Q}}$ \\
\hline $\begin{array}{l}\text { t-Cinnamic } \\
\text { acid }\end{array}$ & 148.16 & 1.79 & 1 & 2 & 43.11 & 11 & 6 & 2 & $37.30 \AA$ & soluble & High & Yes & No & 0.85 & 0 & 1.67 & No & Yes $\stackrel{n}{c}$ \\
\hline $\begin{array}{l}\text { p-coumaric } \\
\text { acid }\end{array}$ & 164.16 & 1.26 & 2 & 3 & 45.13 & 12 & 6 & 2 & $57.53 \AA$ & soluble & High & Yes & No & 0.85 & 0 & 1.61 & No & 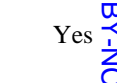 \\
\hline Caffeic acid & 180.16 & 0.93 & 3 & 4 & 47.16 & 13 & 6 & 2 & $77.76 \AA$ & very soluble & High & Yes & No & 0.56 & 1 & 1.81 & No & Yes \\
\hline
\end{tabular}


Hydroxycinnamic acid

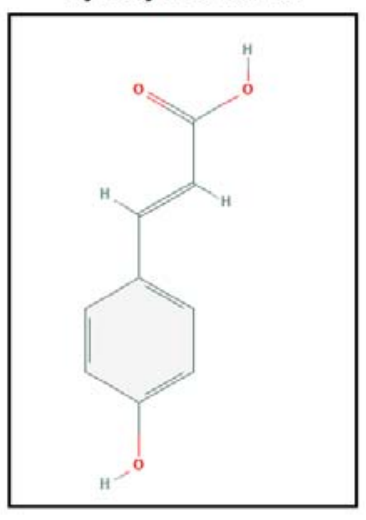

Chrysin

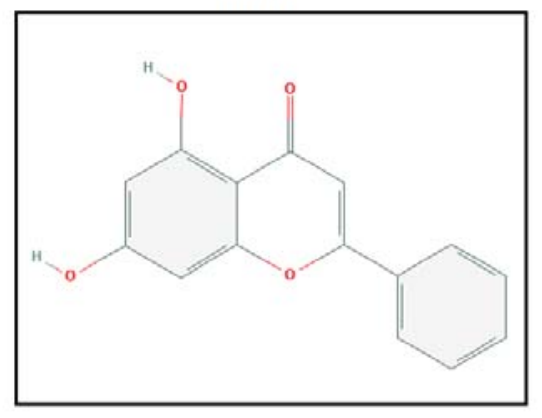

Caffeic acid

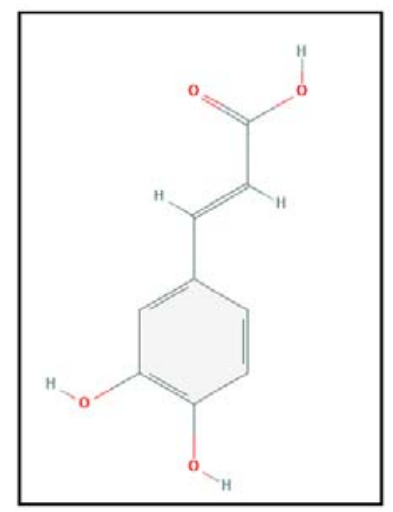

Cinnamic acid

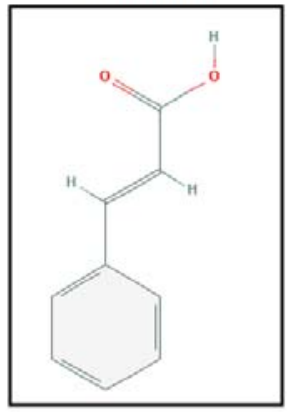

Hesperetin

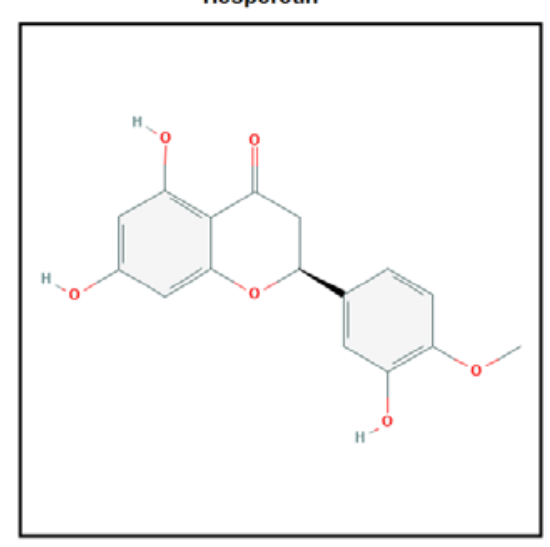

Caffeic acid phenethyl ester

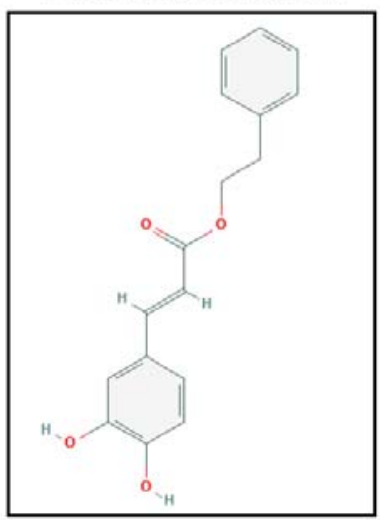

Pinocembrin

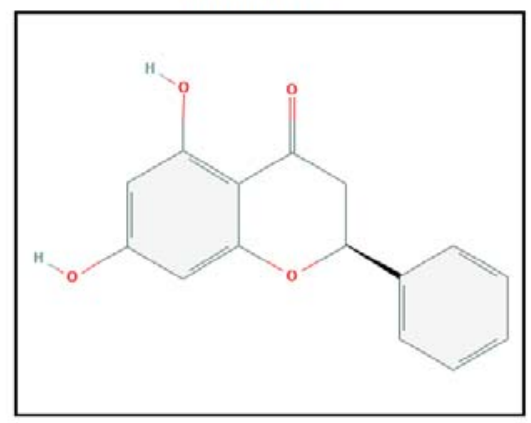

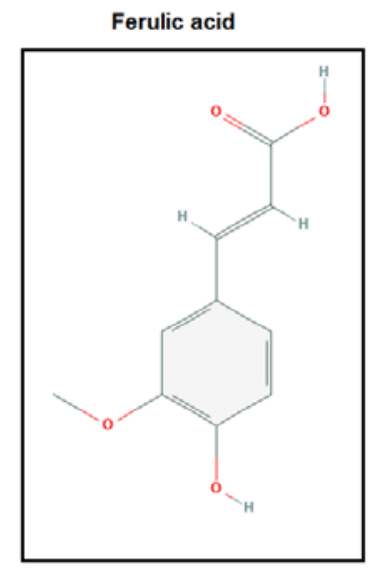

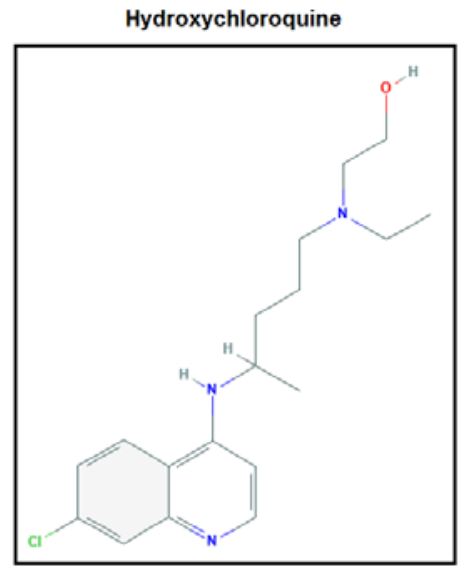

Fig. 1. 2-D structures of ligands used in the present study 


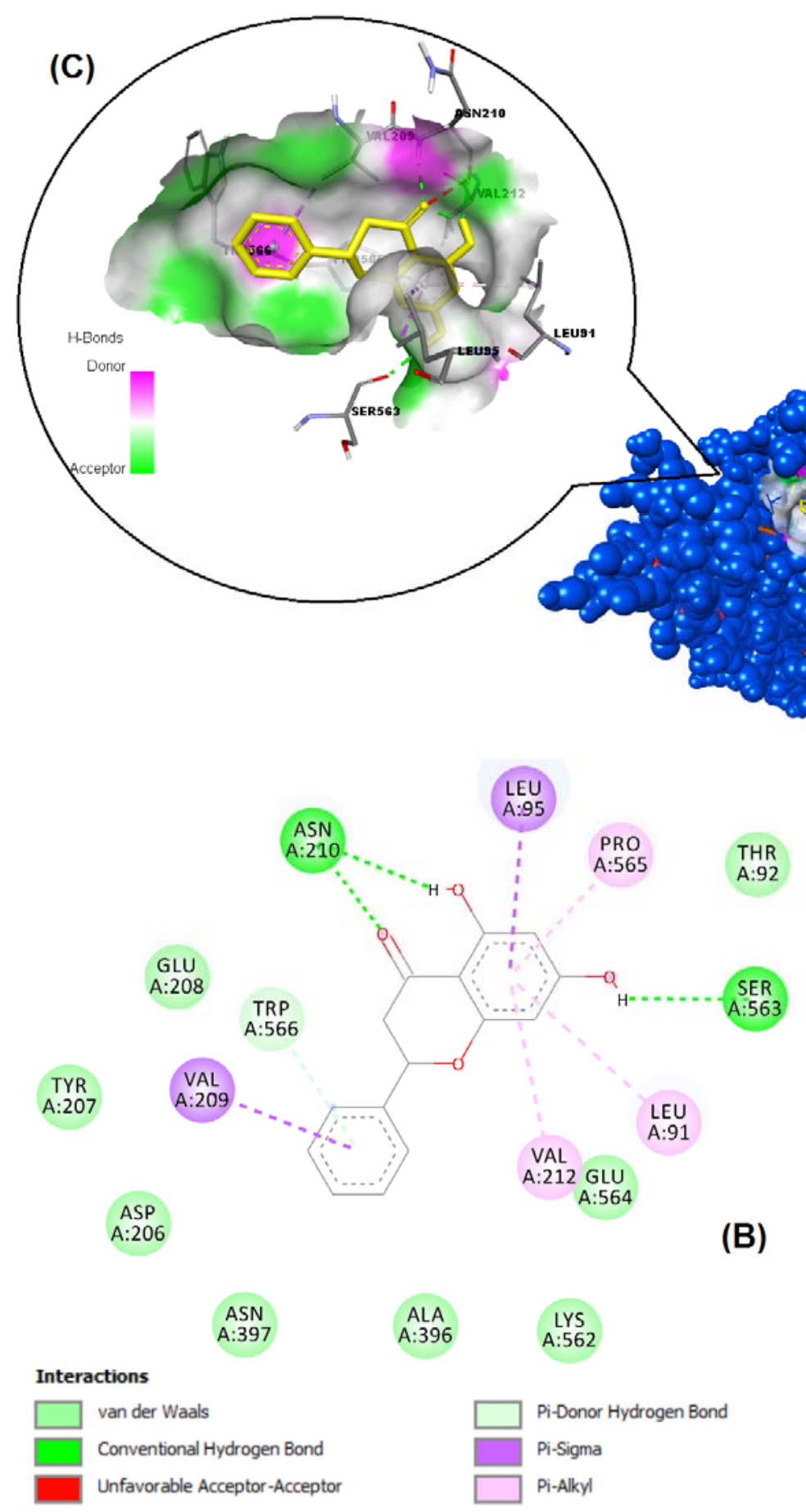

(A)

Fig. 2. Binding pose profile of pinocembrin in the target protein ACE2 (A), blue shaped molecule represents the receptor and yellow shaped molecule indicates the ligand. The two-dimension (2D) (B) and three-dimension (3D) (C) interactions analysis of ACE2 protein with compound pinocembrin. 


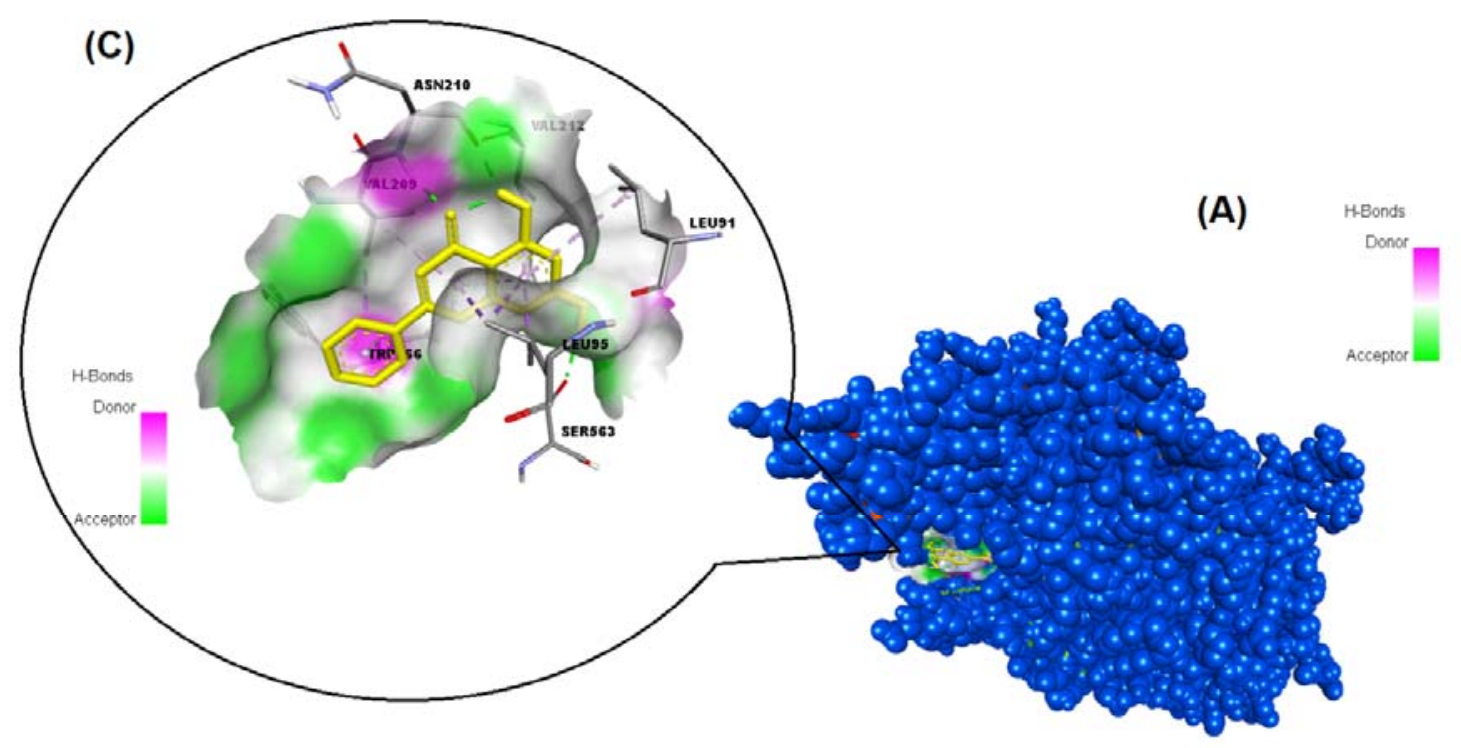

(B)

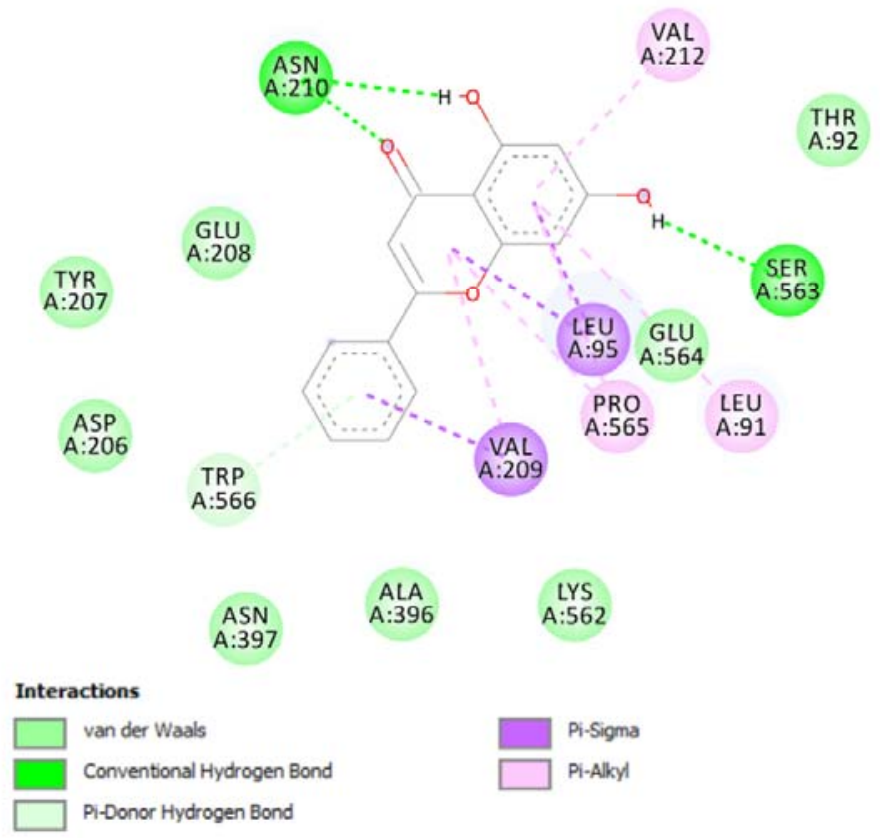

Fig. 3. Binding pose profile of chrysin in the target protein ACE2 (A), blue shaped molecule represents the receptor and yellow shaped molecule indicates the ligand. The two-dimension (2D) (B) and three-dimension (3D) (C) interactions analysis of ACE2 protein with compound chrysin. 


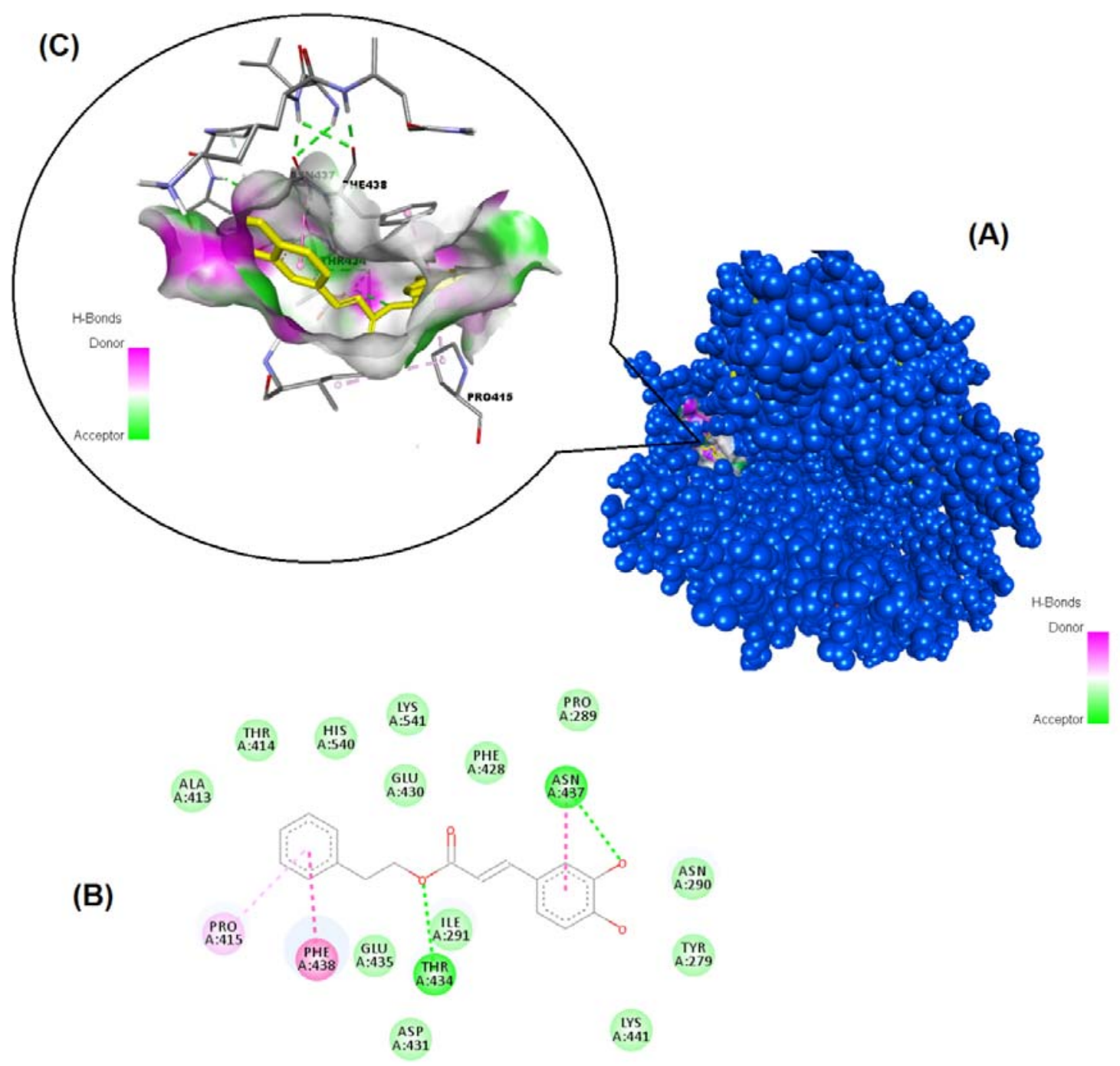

Interactions

van der Waals

Amide-Pi Stacked

Fig. 4. Binding pose profile of CAPE in the target protein ACE2 (A), blue shaped molecule represents the receptor and yellow shaped molecule indicates the ligand. The two-dimension (2D) (B) and three 


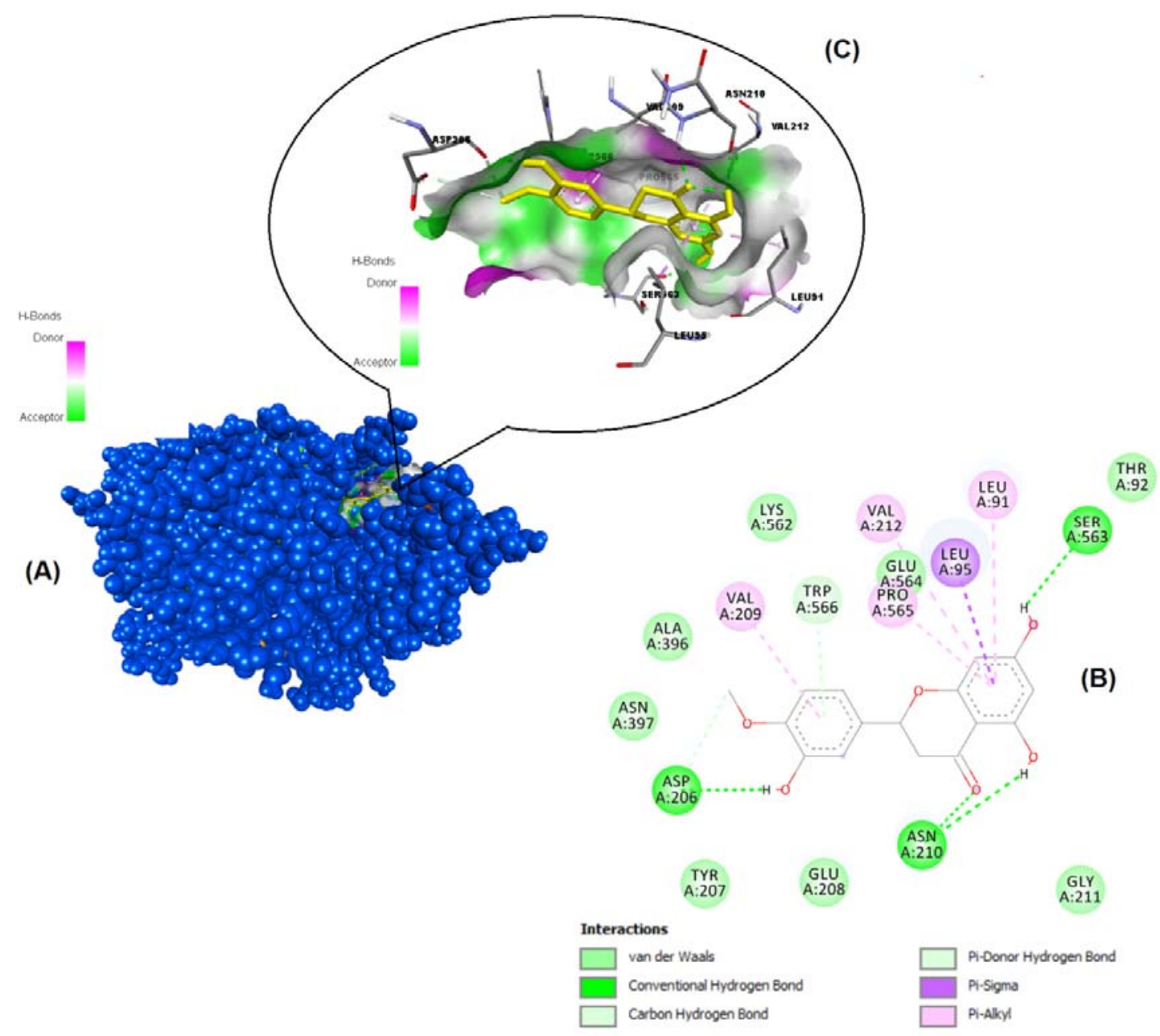

Fig. 5. Binding pose profile of hesperetin in the target protein ACE2 (A), blue shaped molecule represents the receptor and yellow shaped molecule indicates the ligand. The two-dimension (2D) (B) and three-dimension (3D) (C) interactions analysis of ACE2 protein with compound hesperetin. 

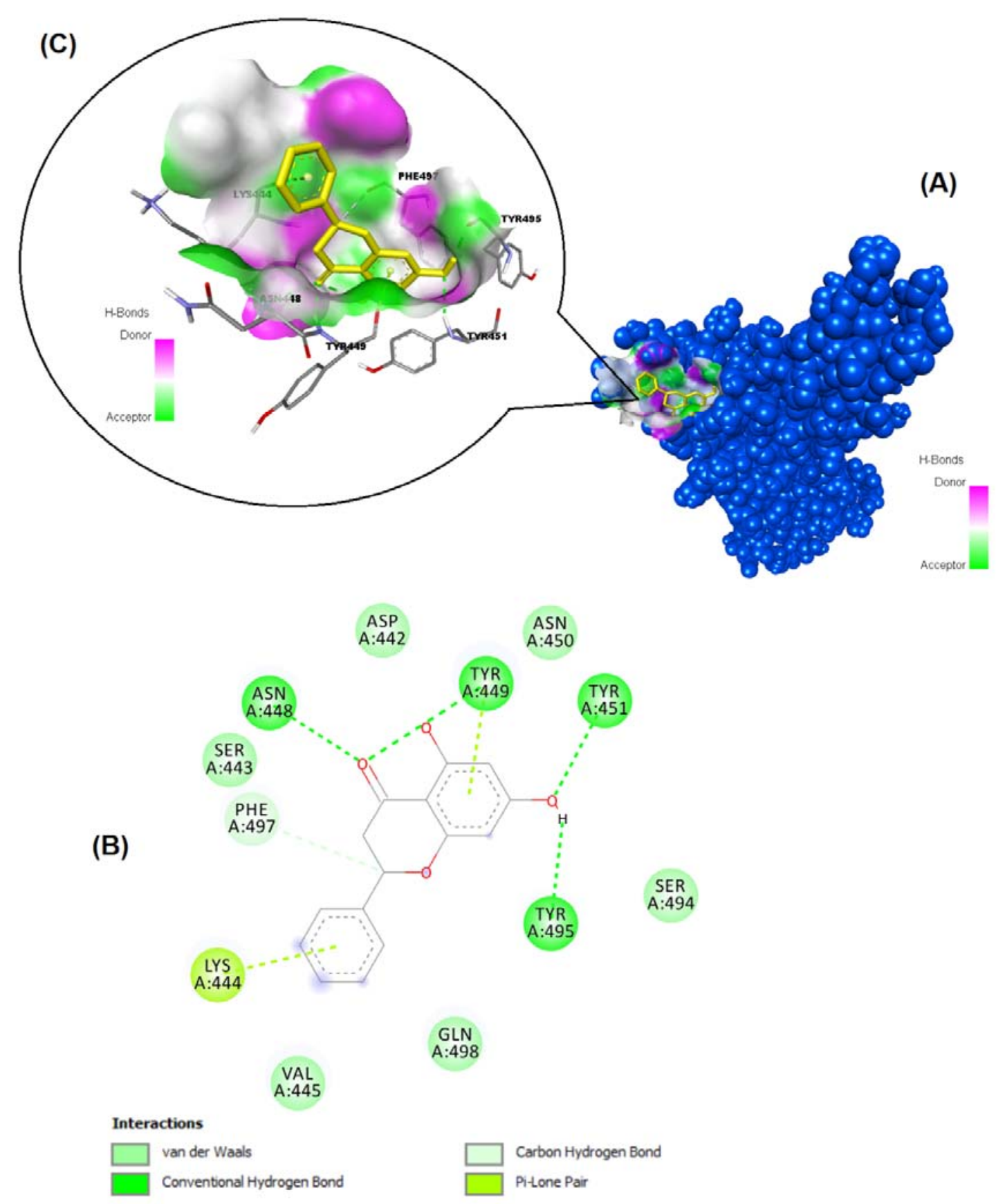

Fig. 6. Binding pose profile of pinocembrin in the SARS-CoV-2 Spike receptor binding domain (A), blue shaped molecule represents the receptor and yellow shaped molecule indicates the ligand. The two-dimension (2D) (B) and three-dimension (3D) (C) interactions analysis of SARS-CoV-2 Spike RBD with compound pinocembrin. 


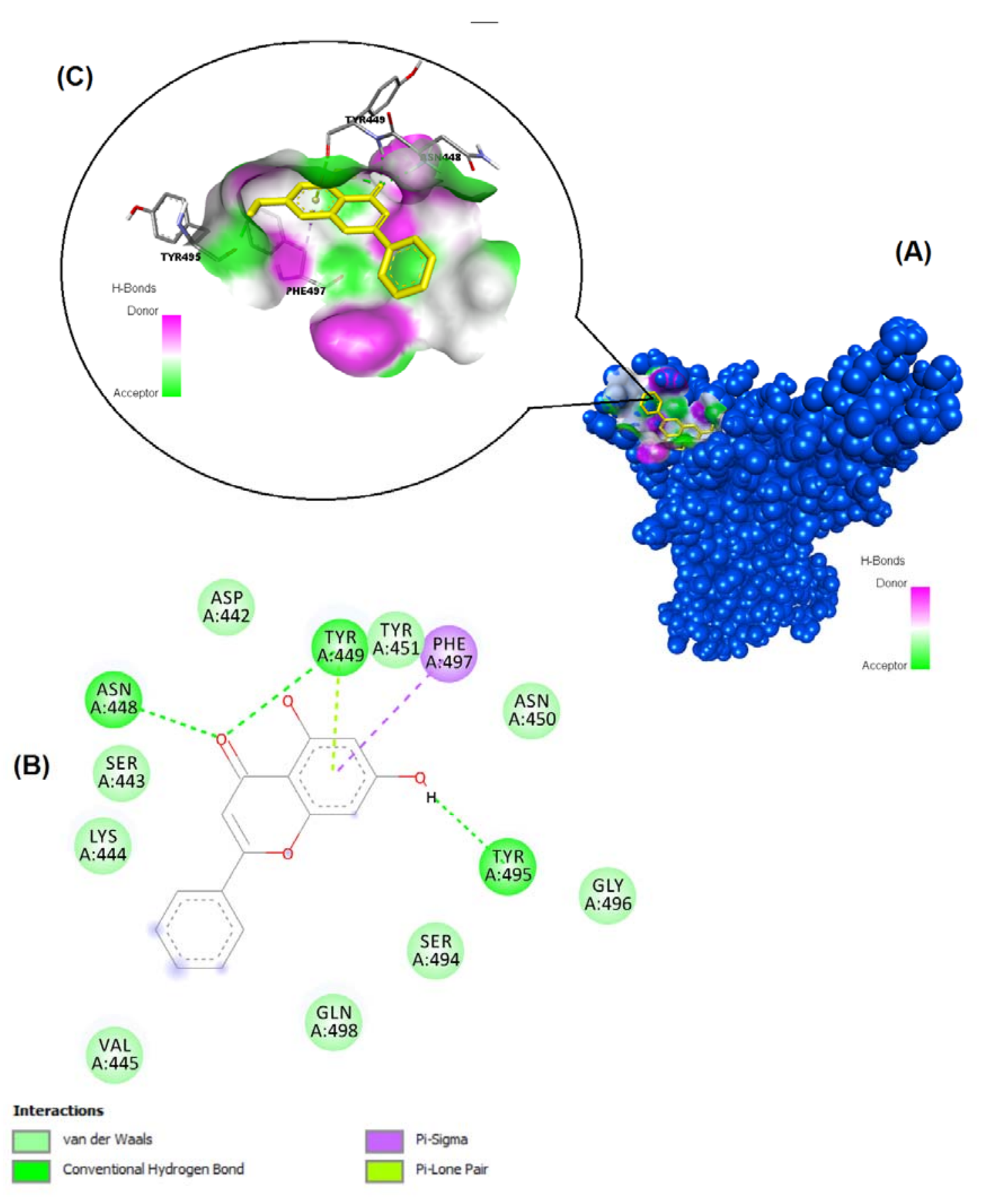

Fig. 7. Binding pose profile of chrysin in the SARS-CoV-2 Spike receptor binding domain (A), blue shaped molecule represents the receptor and yellow shaped molecule indicates the ligand. The twodimension (2D) (B) and three-dimension (3D) (C) interactions analysis of SARS-CoV-2 Spike RBD with compound chrysin. 

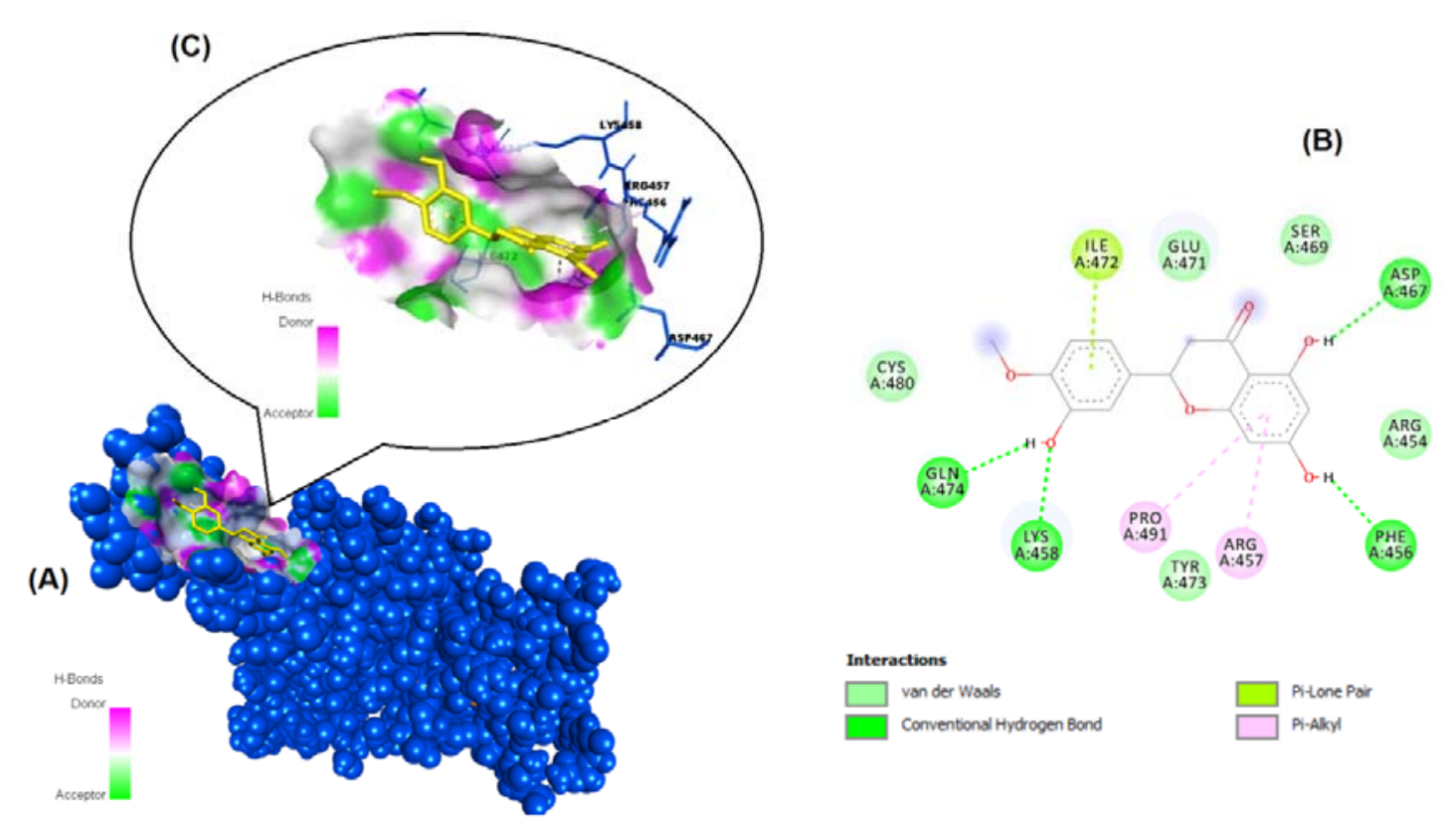

Fig. 8. Binding pose profile of hesperetin in the SARS-CoV-2 Spike receptor binding domain (A), blue shaped molecule represents the receptor and yellow shaped molecule indicates the ligand. The two-dimension (2D) (B) and three-dimension (3D) (C) interactions analysis of SARS-CoV-2 Spike RBD with compound hesperetin. 


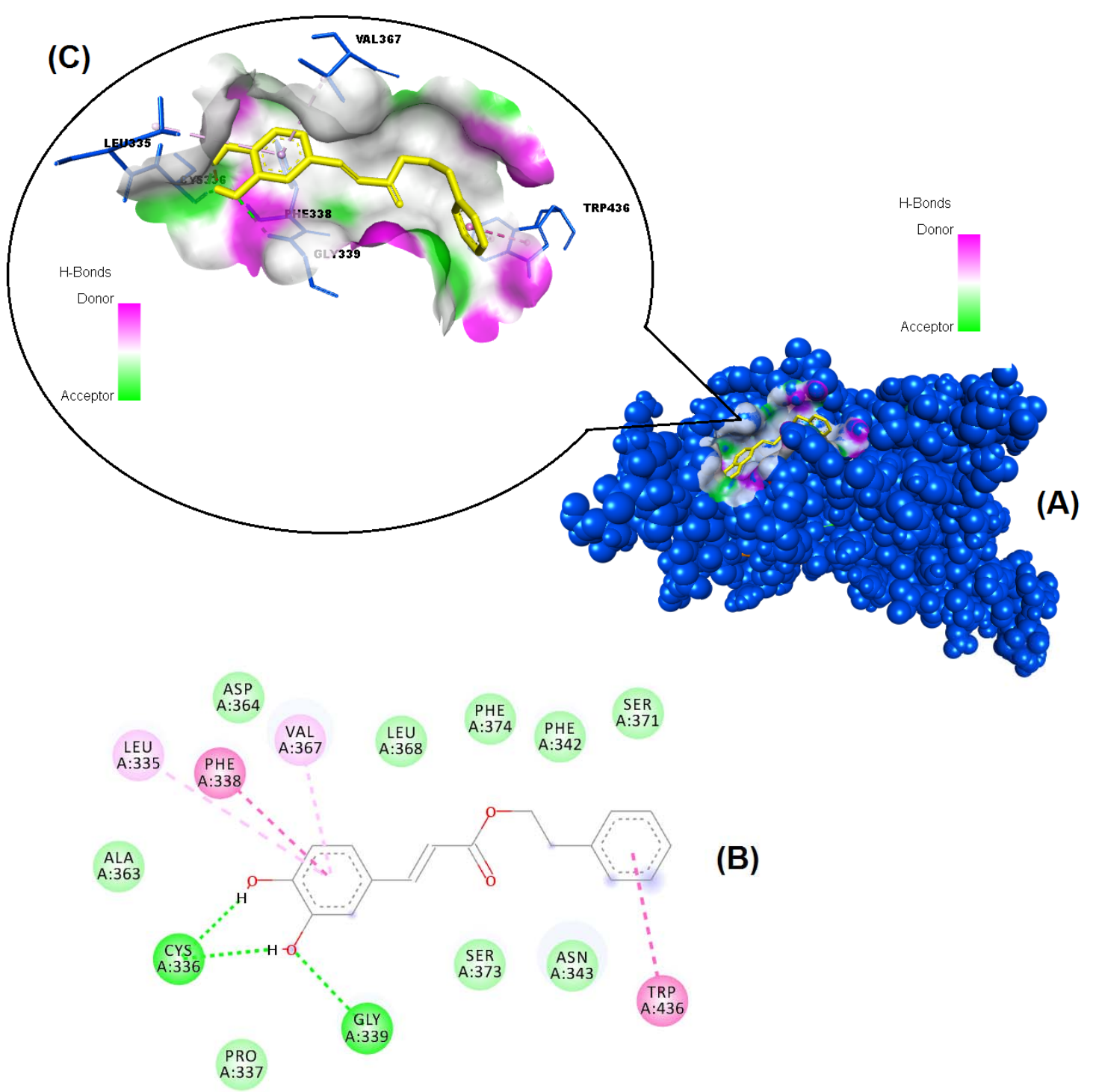

Interactions

Fig. 9. Binding pose profile of CAPE in the SARS-CoV-2 Spike receptor binding domain (A), blue shaped molecule represents the receptor and yellow shaped molecule indicates the ligand. The twodimension (2D) (B) and three-dimension (3D) (C) interactions analysis of SARS-CoV-2 Spike RBD with compound CAPE. 
bioRxiv preprint doi: https://doi.org/10.1101/2021.02.22.432207; this version posted February 23, 2021. The copyright holder for this preprint (which was not certified by peer review) is the author/funder, who has granted bioRxiv a license to display the preprint in perpetuity. It is made available under aCC-BY-NC-ND 4.0 International license.

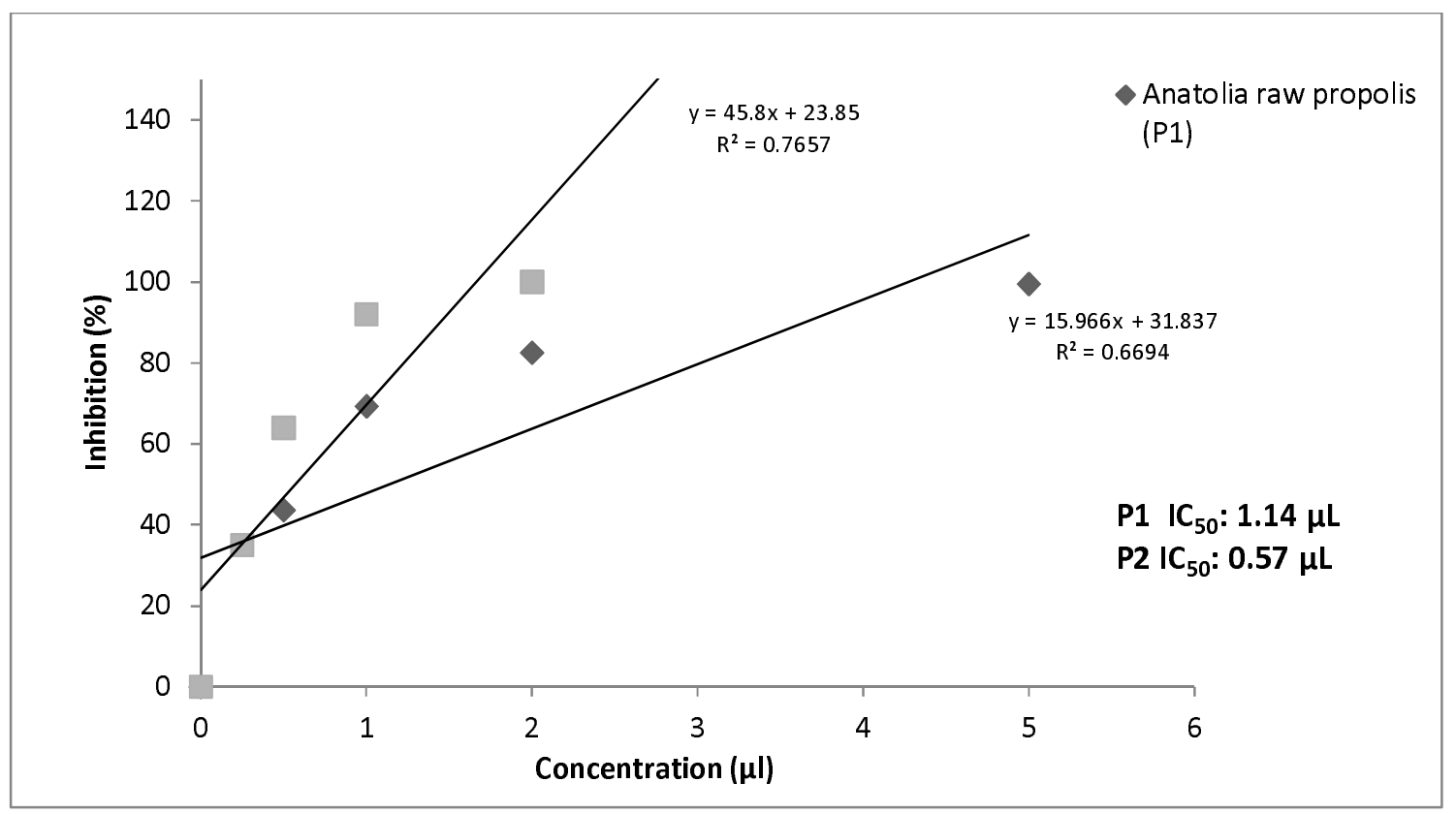

Fig. 10. $\mathrm{IC}_{50}$ values of $\mathrm{P} 1$ and $\mathrm{P} 2$ samples 
bioRxiv preprint doi: https://doi.org/10.1101/2021.02.22 432207· this version posted February 23,2021 . The copyright holder for this preprint (which was not certified by peer review) is the author/funder, who has granted bioRxiv a license to display the preprint in perpetuity. It is made available under aCC-BY-NC-ND 4.0 International license.

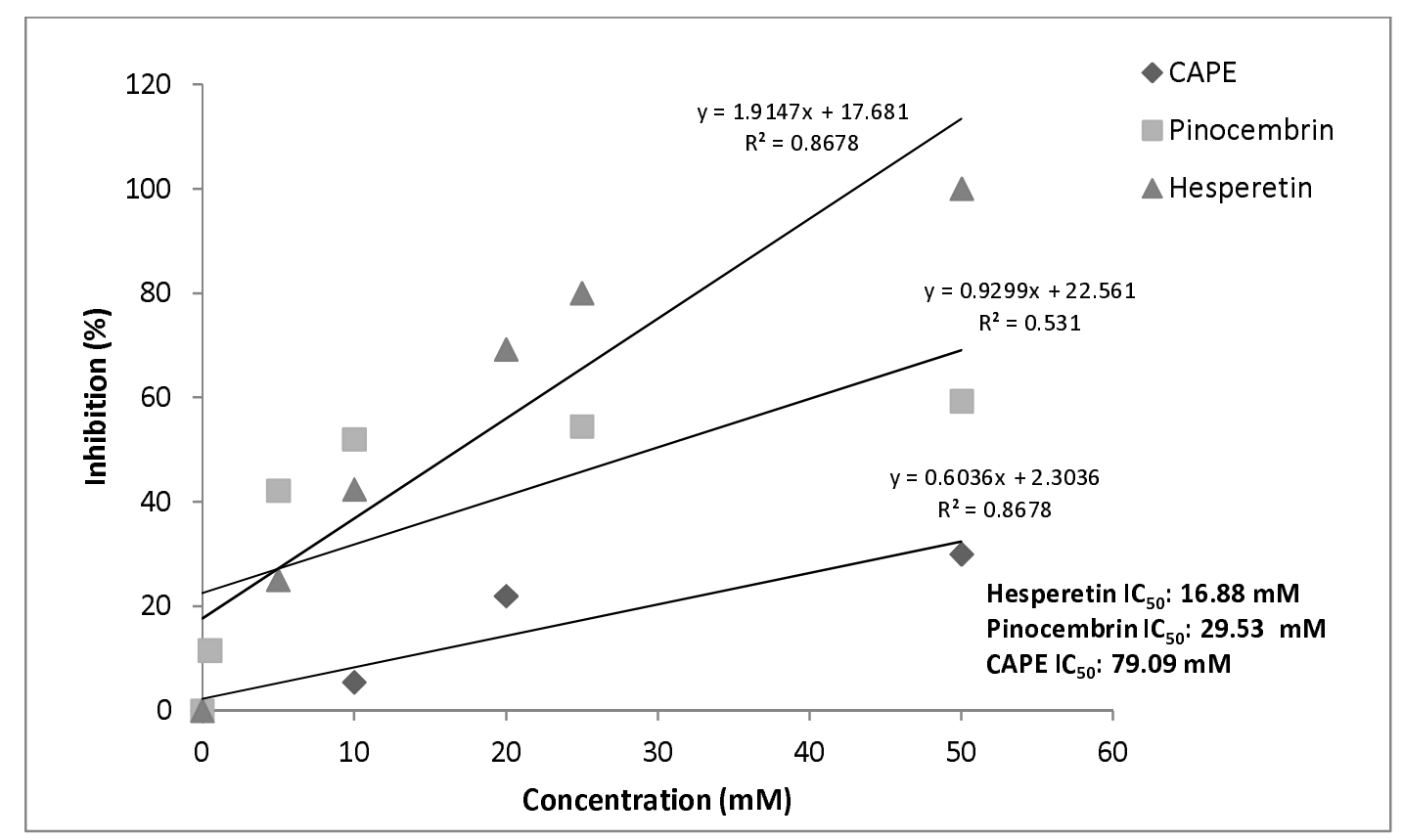

Fig. 11. $\mathrm{IC}_{50}$ values of CAPE, pinocembrin and hesperetin 